\title{
Evaluation of Kubiëna's Contribution to Micropedology. At the Occasion of the Seventieth Anniversary of His Book "Micropedology"1
}

\author{
G. Stoops \\ Laboratorium voor Mineralogie en Petrologie, Vakgroep Geologie en Bodemkunde, WE 13, Universiteit Gent, \\ Krijgslaan 281, S8, B-9000 Gent, Belgium \\ E-mail: georges.stoops@Ugent.be \\ Received November 10, 2008
}

DOI: $10.1134 / \mathrm{S} 1064229309060155$

\section{INTRODUCTION}

Seventy years ago, in 1938, W.L. Kubiëna published his famous book "Micropedology". This is considered as the start of micropedology and Kubiëna as the spiritual father of this discipline. The ideas published in this book still influence the present day soil science, and it is therefore interesting to evaluate their impact and, as a tribute to Kubiëna, to make an overview of his intellectual heritage. In this paper the author will concentrate on Kubiëna's contributions to the present-day status of micromorphology, rather than on those dealing with classification and genesis, although also very important.

Walter L. Kubiëna was born 30th of June 1897 in Neutitschein in Moravia that at that moment was part of the Austrian-Hungarian Empire. In 1915 he joined as volunteer the army, but was captured already one year later and transported to Siberia. He could escape in 1920 and return safely through central Asia and India to his home country, where he studied agriculture at the Hochschule für Bodenkultur in Vienna, and geology, bacteriology and mycology at the University. In 1927, he obtained his doctor's degree, and in 1930 he became Dr.habil. In 1932, he studied soil microbiology in the laboratory of the famous Prof. Waksman at the New Brunswick's university.

In 1937 he lectured as Guest Professor at the Iowa State University and published in 1938 his lecture notes entitled "Micropedology". This book gave birth to the new branch of micropedology. The same year he was appointed extraordinary Professor for geology and soil science at the Hochschule für Bodenkultur in Vienna, where he became full-professor in 1941. Later he founded in Weng near Admont (Austria) the "Forschungsstelle für Alpine Bodenkunde". Being offered a position as Guest Professor by the Consejo Superior de Investigationes Cientificas in Madrid he lived in Spain

\footnotetext{
${ }^{1}$ The article is published in the original.
}

from 1950 till 1955 . This stay gave him the opportunity to get better acquainted with Mediterranean and some tropical soils. Here he also published simultaneously in three languages his famous book "Soils of Europe" (Kubiëna 1952; 1953) on classification. Afterwards he became Head of the Laboratory of Soil Science of the Bundesforschungsanstalt für Forst- und Holzwirtschaft in Reinbek (northern Germany) and Professor at the Hamburg University. In Reinbek he was surrounded by a group of young active co-workers, giving a boast to the development of micropedology. Some of the best known are W. Beckmann, E. Geyger, R. SchmidtLorenz and M.-W. von Buch. In Reinbek, Kubiëna stimulated the development and use of quantitative micromorphology, resulting in his book "Die mikromorphometrische Bodenanalyse" published in 1967. In the last years of his life he still studied polar soils in the field. He corrected the galley proofs of his last work "Micromorphological Features in Soil Geography" (1970), summarising his long scientific experience, but never saw the published book. On December 28th, 1971 he passed away in Klagenfurt (Austria) where he settled after his retirement, still working in a small micromorphological laboratory at home. His last manuscripts on soil genesis were published in 1986, edited by his students F. Blümel and F. Solar.

He was honoured with the title of Doctor honoris causa by the Universidad Complutense of Madrid (Spain) in 1968 and by the University of Rio Grande in Brazil, for his contributions to science. He was Honorary member of the Consejo Superior de Investigationes Cientificas (Madrid), the Sociedad Española de Ciencia del Suelo (Madrid), the Leopoldina (1963), the Österreichische Bodenkundliche Gesellschaft (1966), the Deutsche Bodenkundliche Gesellschaft (1967), the International Society of Soil Science (1968) and holder of the Justus von Liebig Prize (1954). This biography is partly based on Mückenhausen (1967), Hoyos de Castro (1970), Jongerius (1971), Gracanin (1971), Fink 
(1971), Schimitschek (1971), Delgado (1988) and Blümel (1992).

Several initiatives were taken in the past to pay tribute to the work and person of W.L. Kubiëna. A first to be mentioned is a special volume of the international journal Geoderma dedicated to micropedology, published in 1967 in the year of his 70th birthday. In 1988, at the occasion of the fiftieth anniversary of the book "Micropedology"; the "Sociedad Española de la Ciencia del Suelo" prepared a special volume of Anales de Edafologia y Agrobiologia (Vol. 47, nos. 1 and 2) devoted to micromorphology. The Österreichischen Mineralogischen Gesellschaft organised in 1992 during a meeting in Stainz (Austria) a symposium in honour of Kubiëna (Mitteilungen der Österreichischen Mineralogischen Gesellschaft, Band 137) under the stimulation of one of his former student, Dr. F. Blümel.

The Subcommission B (Soil Micromorphology) of the International Soil Science Society (ISSS) created in 1984 a "Kubiëna Award", to honour "an outstanding scientist which has contributed in a special way to the development of soil micromorphology" (ISSS Bulletin 1985/2, no. 68, page 25). This Award has been presented meanwhile in 1985 to R. Brewer (Australia) and E. Yarilova (USSR), in 1988 to H.J. Altemüller (Germany), in 1992 to G. Stoops (Belgium), in 1998 to FitzPatrick (UK), in 2001 to L. Wilding (USA) and in 2006 to $\mathrm{H}$. Mücher (The Netherlands) and posthumous to A. Jongerius (The Netherlands).

\section{KUBIËNA'S FIRST PERIOD: MICROPEDOLOGY AS A CONCEPT}

"Micropedology" is the first handbook for the microscopic study of soils. Although some thin section studies of soils were made before 1938, including several by Kubiëna, they are considered only as isolated attempts.

The innovative aspect of "Micropedology" is to be found in both its philosophy and the formulation of new concepts. The new approach of Kubiëna, to study soils as an organised complex entity, rather than as a collection of isolated components, was totally new, and contrasting with the rather chemical approaches commonly adopted in Western soil science in the beginning of the 20 th century. The study of undisturbed and oriented samples by means of stereoscopic and/or microscopic methods was the logic and direct practical solution for this approach.

The concepts made by Kubiëna as tools for these microscopic analyses must be considered as a major contribution to soil morphology and the base of micropedology. His concepts of soil fabric were influenced by the work of his countryman Sander (1930, translated in 1970) founder of the fabric analysis of rocks. Kubiëna's book does not contain sharply formulated definitions, as is usual now, but clear statements that allow the reader to use and develop the concepts.
His lowest level of fabric is the elementary fabric, dealing with the "arrangement of the constituents of lowest order in the soil and their relation to each other". These fabric units of lowest order are "the skeleton of the fabric, which consists mainly of the residues of rock minerals and organisms not decomposable or which are only slowly decomposing", and the fabric plasma, which is "much more easily moved, changed in composition and shape, and redeposited" "generally identical with the finely dispersed and highly active, newlyformed compounds in the soil". The distinction is thus primarily based on stability, not size, although Stephan (1992) suggests that the difference is inspired by the limit of the optical dissolution.

The plasma may be present in a peptised state (dispersed, adhering to grains, waxy appearance) or a pectised state (flocculated, with no affinity to grains, dull appearance). Skeleton is thus considered as the more or less inert part of the soil, whereas the plasma is the more mobile and changeable one, recording the genetic history of the soil. The state of the plasma (pectised versus peptised) also determines the degree of mobility, erodability, etc.

At a higher level, Kubiëna describes, based on structure, higher levels of soil fabric subdivided into aggregates (4 types), blocks (2 types) and coherent soils (12 types) characterised by special features (e.g. calcite coatings, gypsum crystals).

The concepts of this book have strongly influenced the later description systems. First of all the philosophy of studying undisturbed soil materials with a magnifying instrument is at the base of all later micromorphological research. The plasma/skeleton concept has been taken over by Brewer $(1960,1964)$ although slightly differently defined (soluble versus insoluble, mobile versus immobile) and introducing also a size limit $(2 \mu \mathrm{m})$, and later by Stoops and Jongerius (1977) used in Bullock et al. (1985) and Stoops (2003) as a purely morphometric defined coarse/fine material concept without genetic criteria. These concepts were criticised by FitzPatrick (1993) on the base that in some soils it is difficult to distinguish a coarse and a fine fraction because there is a gradual change in grain size. The omission of genetic criteria is a necessity if one wants to separate objective description from interpretation. This has the advantage that, if there is an evolution in science, the old descriptions can be reinterpreted, what is not the case if genetically based concepts are used.

Also the concept of elementary fabric has survived largely. The skeleton grain/fabric plasma related distribution patterns of Brewer $(1990,1964)$ are based on the same idea, but do not take into account the different stages (pectic versus peptic) or composition (e.g. calcitic) of the plasma. Other similar patterns were proposed by Brewer and Pawluk (1975) and Eswaran and Baños (1976), the latter taking into account the general grain size distribution of the material (see also discussion in Stoops and Eswaran, 1986). 
It is interesting to note that Kubiëna relied for his interpretations not only on optical observations, but that he applied several simple staining and/or heating tests to the studied material, a technique mostly forgotten in recent research. In his book of 1938 he also discussed the study of grain mounts and debris preparations.

\section{KUBIËNA'S SECOND PERIOD: MICROPEDOLOGY IN FUNCTION OF SOIL CLASSIFICATION}

Studying the genesis and classification of soils, Kubiëna realised that each soil type has a distinct microfabric that he summarised in one term (Kubiëna 1948, 1952, 1970). A discussion of his work in the field of genesis and classification is however outside the frame of this paper, but it is clear that his micromorphological concepts cannot be considered isolated from the genetic and taxonomic ones. A number of both terrestrial and subaqueous subsoils and organic horizons were studied and named. For terrestrial subsoils his separation in Lehm and Erde, based on older German concepts (Vageler, 1930; Wohltmann, 1892) is the most interesting. Whereas Lehm represents an early or intermediate transient stage of evolution, Erde is rather an immobile end member. The Lehm stage is characterised by a uniform and dense "peptised plasma" with a porphyric c/f related distribution pattern and displaying flow structures (striated b-fabrics and/or anisotropic clay coatings), expressing mobility of clay and iron. Depending upon the colour, Braunlehm (yellow) and Rotlehm (red or orange) are distinguished. The Braunlehm is typical for the limestone Terra Fusca, the Rotlehm for the Terra Rossa soils. In the Erde the plasma is "pectised", this means flocculated, less uniform and dense, and without flow structures, expressing immobility of the material. Also here a Braunerde (brown) and Roterde (red) is distinguished, the former found in temperate Braunerde, Sol Brun, Cambisol, the latter in red tropical soils, such as Ferralsols. The evolution of the iron oxides plays an important role in the characterisation, as summarised in Kubiëna (1962) (see figure). In Braunlehm iron is supposed to be mobile, probably dispersed by amorphous silica, in Braunerde it is flocculated, and in Rotlehm and Roterde it gradually transforms to hematite and goethite. It is important to note that, in the idea of Kubiëna, the evolution only occurs in one direction (figure).

Studying Bt horizons Kubiëna (1956) was confronted with the fact that part of the material (the ped interior) had Braunerde characteristics, whereas other parts (the clay coatings) display Braunlehm characteristics. He solved the problem by introducing the term Braunerde and Braunlehm Teilplasma, based on the petrographic concept of partial fabric (Teilgefüge).

Apart from the subsurface materials, Kubiëna proposed an interesting subdivision and characterisation of surface horizons, especially with respect to humus of which he described 18 forms and varieties (e.g. Moder,
Mull, Mor, Anmoor, Gytja). They were further extended and detailed by several authors, for instance Jongerius (1957).

As new materials were studied, not discussed in the publications of Kubiëna, new terms were introduced by other authors, such as Weisslehm and Gelblehm by De Craene and Laruelle (1955), referring to greyish white and yellow saprolitic material.

This second system of Kubiëna, that we will call the Lehm/Erde system, has been widely used throughout the world till the end of the sixties, when the system of Brewer (1964) became more general, as it allowed more objective and detailed descriptions and could be applied to exotic soils all over the world, not fitting in Kubiëna's classification. It has been used later mainly by some authors working on loess palaeosols, where it still proved useful to compare profiles. The types of organic horizons described by Kubiëna are still often used in publications, as no better alternatives were proposed on that level.

The advantages of the Lehm/Erde system of Kubiëna are that there is no need to make long and tedious descriptions, allowing a fast and easy comparison between materials, and that a single term allows to describe a soil fabric immediately related to a soil or horizon type. Apart from these technical advantages the system has the merit to try to link micropedology directly to soil classification, based on genetic concepts. There are however also disadvantages. The system is limited de facto to the soils described and classified by Kubiëna. Application to other soils would need the introduction of many more terms (especially for arid and humid tropical soils), leading to an uncontrolled and probably chaotic proliferation of terms. Accepting the terminology automatically implies the acceptance of Kubiëna's viewpoints on soil evolution, whereby the Braunlehm is the origin of all other types, which are considered end members. This evolution is supposed to be irreversible, what is not confirmed by modern research. In Kubiëna's view, explained in his books $(1948,1970)$ soils can be ordered according to the principles of Carolus Linnaeus, as branches of a tree. Moreover it is a fact that several mechanisms proposed by Kubiëna were not supported by other data than those of field- and microscope observations, and therefore not always corresponding to the present-day understanding of soil genesis. Finally, one has to state that much information is lost as it is not necessary to make a complete description of the thin section.

\section{MICROMORPHOMETRY}

During his Reinbek period, Kubiëna got convinced of the need of quantitative methods in soil micromorphology, in order to coop with the new fashion of expressing every property in numbers, and to make micromorphology a tool for applied soil science. He realised however that not all fabric elements can be 


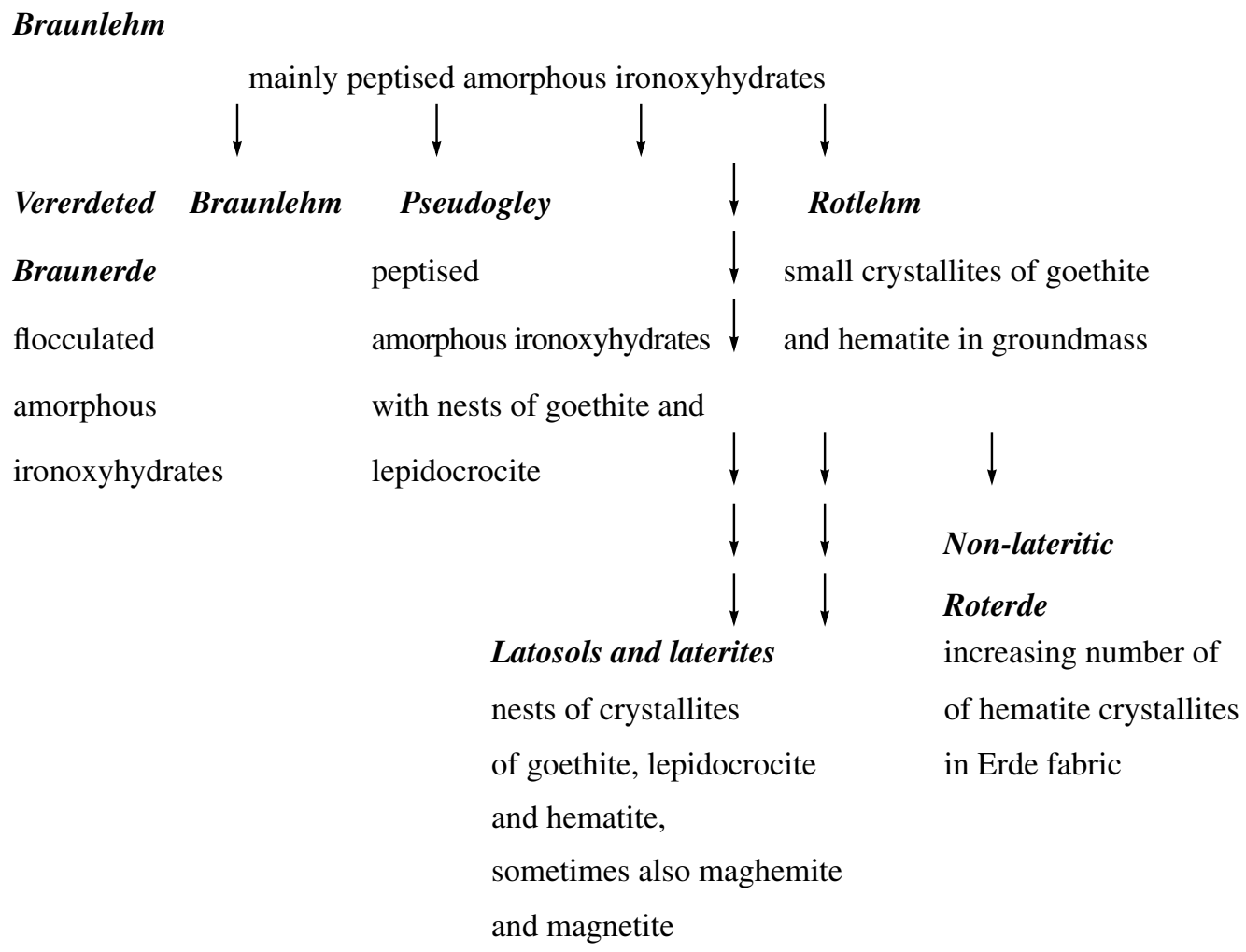

Taxonomic value of ironoxyhydrates as a base of the Lehm/Erde system (according to Kubiëna, 1962).

quantified, and that for many quantification has no surplus value (Kubiëna, 1967b). Under his stimulation his students, W. Beckmann and E. Geyger made quantitative studies on soil porosity. His book "Die Mikromorphometrische Bodenanalyse" (1967a) has given an important impulse to quantification. The parts on methodology were however, rather quickly outdated because of the fact that automatic systems for image analyses became available at the end of the sixties (Jongerius et al., 1972). One of the papers of this book (Beckman and Geyger, 1967), combining void patterns and aggregates to structure types, had an important theoretical impact on the development of the chapter on soil microstructure in Bullock et al. (1985).

\section{DISCUSSION AND CONCLUSIONS}

The work of W.L. Kubiëna has without doubt an important impact in the field of soil genesis and classification (several national European systems were based on it), and especially on micropedology, that would not have reached so quickly the status and level it has now. Micropedology became an internationally recognised discipline with its own specific international working meetings every four years, and separate sessions in many national and international congresses. Kubiëna's philosophy of studying undisturbed soils with the help of magnifying instruments is still at the base of all micropedological research ranging from a stereomicro- scope to the most powerful electron microscope and microprobes working on nm level. Several of his concepts, such as dividing the soil material in a coarse stable and a fine mobile fraction (skeleton/plasma) and his elementary fabrics (c/f related distributions) are still the base of modern descriptive systems. Both his systems were appreciated in the USSR. This may be explained probably by the fact that Kubiëna's approach to soil science was influenced by his admiration for the old Russian masters such as Dokuchaev and Glinka, and that his vision on soil classification and geography was on the same line (zonal, genetic) as that of most USSR scientists. Other reasons may be that his book was well known amongst Soviet scientists. Sometimes his ideas were adapted to local needs. For instance Lobova, (1967) introduced the concept of "ferrugination" for soils of boreal and desert areas to complement Kubiëna's concepts of rubefaction and laterization for tropical soils, both characterised by specific micromorphological fabrics. Concepts were taken over, but the terminology often adapted and completed (Parfenova and Yarilova, 1965, Dobrovol'sky 1983) with terms based on well developed concepts derived from sedimentary petrography (e.g. Rukhin, 1953, Strakhov, 1957). For instance the term plasma was replaced by fine dispersed material, clay, humus-clay, carbonateclay, and terms such as scaly and fibrous microtextures of the fine dispersed mass were used. It is very important to notice that many of these sedimentary concepts 
were already more in line with the later Brewer (1964) system, and even used in Bullock et al. (1985) and Stoops (2003).

The classification system proposed by Kubiëna $(1952,1953)$ was published at a moment that a new, non-genetic system was in development in the USA and strongly supported in some European countries. It therefore had no fair chance to become internationally used, as also the FAO later choose for a non-genetic approach. In these systems micropedology had no chance to play an important role as this discipline was less popular in soil survey communities of the USA than in Europe and Russia, where Kubiëna's approaches were more commonly recognised, e.g. in their classification systems with a strong genetic base. This is however a most regrettable situation as the use of micromorphology would have made it possible to elaborate a more efficient classification system. It would for instance allow to define better subdivisions for different horizons, especially the Cambic, but also the Calcic, the Gypsic and even the Argillic (Argic). A classification supported by micromorphological data would be for sure closer to the natural reality.

\section{ACKNOWLEDGMENTS}

The author expresses his thanks to Dr. M. Gerasimova for her positive critics and encouragement.

\section{REFERENCES}

1. W. Beckmann and E. Geyger, "Entwurf einer Ordnung der Naturlichen Hohlraum-, Aggregat- und Struktur-Formen im Boden," in Die Mikromorphometrische Bodenanalyse, Ed. by W. L. Kubiëna (Ferdinand Enke Verlag, Stuttgart, 1967), pp. 165-188.

2. F. Blümel, "W. Kubiëna und die Anfänge der Mikromorphologie in Österreich," Mitteilungen der Österreichischen Mineralogischen Gesellschaft 137, 129-130 (1992).

3. R. Brewer, "The Petrographic Approach to the Study of Soils, in 27 Int. Congr. Soil Sci. (Madison, 1960), Vol. 1, pp. 1-13.

4. R. Brewer, Fabric and Mineral Analysis of Soils (John Wiley \& Sons, New York, 1964), p. 470.

5. R. Brewer and S. Pawluk, "Investigations of Some Soils Developed in Hummocks of the Canadian SubArctic and Southern Arctic Regions, I. Morphology and Micromorphology," Can. J. Soil Sci. 55, 301-319 (1975).

6. P. Bullock, N. Fedoroff, A. Jongerius, G. Stoops, T. Tursina, and U. Babel, Handbook for Soil Thin Section Description. Waine Research Publications (Wolverhampton, UK, 1985), p. 152.

7. A. De Craene and J. Laruelle, "Genèse et altération des Latosols équatoriaux et tropicaux humides," Bull. Agricole de Congo Beige 46, 1113-1245 (1955).

8. M. Delgado, Introduccion. Anales de Edafologia y Agrobiologie 47, Número Homenaje al Prof. Kubiëna, 9-14 (1988).
9. G. V. Dobrovol'ski, A Methodological Manual of Soil Micromorphology, Ed. by K. Oorts (ITC-Gent, 1991), p. 63 [in Russian].

10. H. Eswaran, and C. Baños, "Related Distribution Patterns in Soils and Their Significance," Anales de Edafologia y Agrobiologia 35, 33-45 (1976).

11. J. Fink, "Prof. Dr. Walter Kubiëna," Bull. Int. Soc. Soil Sci. 38, 27-29 (1971).

12. E. A. FitzPatrick, Soil Microscopy and Micromorphology (J. Wiley \& Sons, Chichester, 1993), p. 304.

13. Z. Gracanin, "Prof. Dr. Walter Kubiëna," Bull. Int. Soc. Soil Sci. 38, 27 (1971).

14. A. Hoyos de Castro, "Profesor W. Kubiëna ( $\dagger$ )," Anales de Edafologia y Agrobiologie 29, 953-957 (1970).

15. A. Jongerius, Morfologische onderzoekingen over de Bodemstructuur. Bodemkundige Studies No. 2: Mededelingen van de Stichting voor Bodemkartering (Wageningen, The Netherlands, 1957), p. 93.

16. A. Jongerius, "In Memoriam Prof. Dr. Walter L. Kubiëna (1897-1970)," Geoderma 5, 249-250 (1971).

17. A. Jongerius, D. Schoonderbeek, and A. Jager, "The Application of the Quantimet 720 in Soil Micromorphometry," Microscope 20, 243-254 (1972).

18. W. L. Kubiëna, Micropedology (Collegiate Press, Ames, Iowa, 1938), p. 243.

19. W. L. Kubiëna, Entwicklungslehre des Bodens (SpringerVerlag, Wien, 1948), p. 215.

20. W. L. Kubiëna, Claves Systematicos de Suelos CSIC (Madrid, 1952), p. 388.

21. W. L. Kubiëna, The Soils of Europe (Thomas Murby \& Co., London, 1953), p. 314.

22. W. L. Kubiëna, Bestimmungsbuch und Systematik der Böden Europas (Ferdinand Enke Verlag, Stuttgart, 1953), p. 388.

23. W. L. Kubiëna, "Zur Mikromorfologie, Systematik und Entwicklung der rezenten und fossilen Lössboden," Eiszeitalter und Gegenwart 7, 102-112 (1956).

24. W. L. Kubiëna, "Die Taxonomische Bedeutung der Art und Ausbildung von Eisenoxydhydrat-Mineralien in Tropenböden," in Arbeiten aus dem Gebiet der Mikromorphologie des Bodens, Ed. by H.-J. Altemüller and H. Frese (Verlag Chemie, Weinheim, 1962), pp. 95-103.

25. W. L. Kubiëna, Die Mikromorphometrische Bodenanalyse (Ferd. Enke Verlag, Stuttgart, 1967a), p. 188.

26. W. L. Kubiëna, "Mikromorphologie und Mikromorphometrie," in Die Mikromorphometrische Bodenanalyse, Ed. by W. L. Kubiëna (Ferdinand Enke Verlag, Stuttgart, 1967b), pp. 4-18.

27. W. L. Kubiëna, Micromorphological Features of Soil Geography (Rutgers University Press, New Brunswick, New Jersey, 1970), p. 254.

28. W. L. Kubiëna, Grundzüge der Geopedologie und der Formenwandel der Böden (Agrarverlag, Wien, 1986), p. 128.

29. E. V. Lobova, Soils of the Desert Zone of the U.S.S.R. Israel Program for Scientific Translation (Jerusalem, 1967), p. 405.

30. Mückenhausen, "Das wissenschaftliche Werk van Prof. h.c. Dr. Dr. h.c. Walter L. Kubiëna," Geoderma 1, 165174 (1967). 
31. E. I. Parfenova and E. A. Yarilova, Mineralogical Investigations in Soil Science. Israel Programme for Scientific Translations (Moskva, 1962; Jerusalem, 1965), p. 178.

32. L. B. Rukhin, Grundzüge der Lithologie (Russia, 1953; Akademie Verlag, Berlin, 1958), p. 806.

33. B. Sander, Gefügekunde der Gesteine (Wien, 1930).

34. B. Sander, An Introduction to the Study of Fabrics of Geological Bodies (Pergamon Press, Oxford, 1970), p. 631.

35. E. Schimitschek, "Prof. Dipl.-Ing. Dr. Dr. H.c. Walter Kubiëna zum Gedanken,” J. Pest Sci. 44, 76-77 (1971).

36. S. Stephan, “Über den Wechsel der Bodeneigenschaften an der lichtoptischen Auflösungsgrenze," Mitteilunger der Österreichischen Mineralogischen Gesellschaft 137, 205-206 (1992).
37. G. Stoops, Guidelines for the Analysis and Description of Soil and Regolith Thin Sections (SSSA, Madison, WL, 2003), p. 184.

38. G. Stoops and H. Eswaran, Soil Micromorphology (Van Nostrand Reinhold Company, New York, 1986), p. 345.

39. G. Stoops and A. Jongerius, "Proposals for a Micromorphological classification of Soil Materials, Vol. I: A Classification of Related Distribution of Coarse and Fine Particles. A reply," Geoderma 19, 247-249 (1977).

40. N. M. Strakhov, Méthode d'étude des roches sédimentaires, Tome 1: Annales du Service d'information Géologique (BRGM, 1957), p. 542.

41. P. W. E. Vageler, Grundriss der tropischen und subtropischen Bodenkunde, 2 Vols. (Verlaggesellschaft für Ackerbau. Berlin, 1930).

42. F. Wohltmann, Handbuch der tropischen Agrikultur (1892). 